\title{
An Event Study of the Zimbabwe Stock Exchange (ZSE): Implications for Post-Dollarisation Market Efficiency
}

\author{
Taonaziso Chowa*
}

\author{
Alois I. Nyanhete \\ Richard Mhlanga \\ National University of Science and Technology (NUST), Zimbabwe \\ *E-mail: teechowa@gmail.com
}

\section{Doi:10.5901/mjss.2014.v5n3p273}

\begin{abstract}
This paper investigates the impact of earnings (full-year, half-year and dividend) announcements and cautionary statements on returns of ZSE listed companies post-dollarisation of the economy in 2009. A standard CMRM based event study methodology (EVM) is applied to weekly returns from January 2010 to December 2012. Findings suggest that earnings announcements and cautionary statements have no impact on returns of companies traded on the ZSE characterised by a very weak correlation of between 'good/bad news' and the direction of significant CARs. We conclude that alleged insider trading, high costs of trading and market undervaluation make it difficult for EVM to detect abnormal returns, thereby painting picture of compliance with the weak to semi-strong forms of the Efficient Market Hypothesis (EMH).
\end{abstract}

Keywords: Dollarisation, Public Announcements, Event study, ZSE, Market efficiency, PEAD, CMRM, Abnormal Return

\section{Introduction}

Zimbabwe fully adopted the 'multi currency system' (referred to as dollarisation in this paper) in January 2009 as announced by the then acting Minister of Finance, Honourable Patrick Chinamasa (Chinamasa, 2009). The close of year 2008 had seen suspension of trade on the Zimbabwe Stock Exchange (ZSE) on 18 November 2008 (ZSE Handbook 2010:p.72). The ZSE resumed trading in United States dollars (USD) on the 19th of February 2009 and went through a 'market correction period' of two months to April $20^{\text {th }}$ for all listed shares to have traded at least once. The bourse experienced an aggressive recovery (Legat, 2009), closing year 2009 at a global best of 47 percent, despite liquidity challenges. Growth however decelerated between 2010 and 2012 registering an average annual return of $2.26 \%$ due to limited capital and its high cost as well as policy inconsistencies and political uncertainty from the inclusive Government of Zimbabwe partners. Their issues of disagreements included the implementation of the indigenisation regulations (requiring reductions in all foreign ownership to less than 49\%), the new constitution, national referendum to adopt it, as well as pending national elections, (www.africaneconomicoutlook.com).

The Securities Commission of Zimbabwe (SECZ) in line with the Securities Act of Zimbabwe (Chapter 24:25), carried out investigations regarding 'special bargain'1 trades (The Zimbabwe Independent, 28 October 2011) ${ }^{2}$ and allegations of insider trading (witnessing abnormal stock price jumps during closed periods ${ }^{3}$ or prior to the issuing of a cautionary statement) (The Zimbabwe Standard, 4 March 2010; The Zimbabwe Herald, Friday 27 April 2012; and Bulls n Bears Financial Markets Update, 27 July 2012). Questions on ZSE efficiency have arisen due to some 'evident' information asymmetries.

\footnotetext{
${ }^{1}$ A special bargain, in an equities market is defined as a transaction beyond the market in price and volume, thus a block of shares is acquired for a price that is higher or lower than their actual market value. This practice is however legal on the ZSE hence no prosecutions materialised.

2 ZSE witnessed 75 special bargains with premiums of up to $518 \%$

${ }^{3} \mathrm{~A}$ closed period is the time from a public listed firm's year-end to the date on which the firm's financial results are published and directors of companies, their families and employees who may have certain privileged information about a company are restricted at law from trading shares or any material activity.
} 


\subsection{About the Zimbabwean Stock Exchange (ZSE)}

According to the (ZSE) website (www.zse.co.zW), the bourse was established in 1896 and allowed limited foreign investment from 19934. There are 76 listed firms as at $28^{\text {th }}$ December 2012 with a closing market capitalisation of USD3.8 billion in 18 different economic sectors. Trading on the ZSE is done manually (open cry) and is conducted in a daily call over that begins at 10.00am and ends before noon, with settlement done on a $T+7$ day basis against physical scrip delivery. Zimbabwe's well developed capital market includes active local and foreign ${ }^{5}$ institutional investors supported by 13 registered stock brokers and 5 custodians.

There is a high concentration of shareholding for ZSE listed counters with the top 20 accounting for an average of at least $83 \%$ of the local register and consists largely of more than $85 \%$ local and foreign institutional investors, (CASE Handbook 2011:p.191, 419-456). Liquidity has been relatively low, averaging $11.23 \%$ for the years 2010 and 2011 and dominated by the heavily capitalised 'blue chip' counters. The costs of trading on the ZSE are relatively high totalling $4.21 \%$ split as $1.73 \%$ for buying and $2.48 \%$ when selling as at May 2012. The ZSE is an undervalued market with the listed counters trading at an average discount of $35 \%$ to the net asset value (NAV) during mid 2011. Old Mutual (OM) and Pretoria Portland Cement (PPC) shares are fungible, and may be traded on the JSE, and also the LSE in the case of $\mathrm{OM}$. The bourse is working on the establishment of a central depository and electronic trading systems by the end of year 2013.

\subsection{Purpose of the study}

This study is the first in conducting an event study analysis of the impact of earnings announcements and cautionary statements on the ZSE in the post-dollarisation era and contributes to the literature in the following ways. First, we build on prior researches on ZSE market efficiency by looking at stock price reactions to earnings announcements and cautionary statements. Secondly, we make split comparisons to assess cumulative abnormal returns (CARs) from earnings (full-year, half-year and dividend) announcements and cautionary statements to highlight their respective impacts. Thirdly, we analyse p-values of significant CARs events in order to assess the direction of ARs during 'good news' and 'bad news' events.

\subsection{Organisation of the study}

The rest of this paper is structured as follows: Section 2 reviews the literature on event studies and stock price reactions to earnings announcements. Section 3 presents the data and the methodology used to conduct the study. Section 4 discusses the findings and Section 5 concludes the study.

\section{Literature Review}

\subsection{Event study methodology (EVM)}

According to Grar (1997), as cited in Saidane \& Lavergne (2007), an event is defined as information which is made public on the market and which may affect the value of one or several firms at the same time - it may be general or specific, periodical or occasional, exogenic or decided by the firm managers. Mushidzi \& Ward (2004) assert that event study methodology (EVM) is frequently used to determine whether there is a statistical difference between actual stock returns and required returns surrounding an event, a definition that appears in varying forms and wordings but with albeit the same objective from numerous EVM researchers. Classical EVM approach consists of the three time periods of analysis namely estimation/pre-event window, event window and post-event window, with the event impact being captured by the significance of abnormal returns during the event window.

Mackinlay (1997) assigns the origin of event studies to Dolley (1933) who studied the price effects of stock splits together with other pioneer researchers such as Mayers \& Bakay (1948) and Baker (1956, 1957 and 1958). The current form of EVM was popularised in the 1960s by Ball \& Brown (1968) and Fama et al (1969). Since then EVM has evolved and broadened in scope with diverse applications in the fields of accounting and economics to wider applications in

\footnotetext{
${ }^{4}$ For post 1993 holdings foreign investors may hold up to 10\% of a listed company, and collective foreign ownership cannot exceed $40 \%$ ${ }^{5}$ Foreign participation on the ZSE post-dollarisation has averaged $40 \%$ of the total value of trades.
} 
finance as construed from Binder (1998) making it a powerful tool in EMH research. EVM has been embraced by many other researchers such as Kiger (1972), Aharony \& Swary (1980), Bhana (1995/96), Gajewski \& Quéré (2001), Kong \& Taghavi (2006), Dey \& Radhakrishna (2008) and Louhichi (2008) - all having applied it where security prices respond to new information.

Extensions have been done to apply EVM on the impact of terrorism (Chesney, Reshetar \& Karaman, 2010), celebrity scandals (Tiger Woods) on sponsors' stocks (Hood, 2012) as well as other factors. Hood (2012) also demonstrates that the size of the estimation window has a dramatic impact on the statistics (p-values), even after more than 200 trading days are considered. New directions for simulation based EVMs are emerging such as generalized least squares (GLS) by Graca and Masson (2012) and those based on hidden Markov chains by Saidane \& Lavergne (2007).

\subsection{Stock price reactions to earnings announcements}

Barker \& Imam (2008) suggest that high earnings bring more attention and favour from financial statements users (including investors) than low earnings. Reactions to earnings have been found to be significant subject to factors such as firm size, sector, newspaper reports and the number of analysts following the stock and other factors; (Kiger, 1972; Aharony \& Swary 1980; Mendenhall 1991; Christensen, Smith \& Stuerke 2004 and Deshpande \& Svetina 2011). These empirical findings are a mirror of Fama et al, (1969)'s famous 'signalling hypothesis' by dividends which has received widespread attention in literature (Charest, 1978; McNichols \& Dravid, 1990 and McClusky et al, 2006)

Applying the signalling hypothesis to public announcements and cautionary statements would imply symmetry of response behaviour with respect to whether the news is good or bad. However Dey \& Radhakrishna (2008) and Chordia et al (2009) debate the profitability of trading before or after the announcements for both institutions and individuals due to an observed 'short-term post-event reversal' and transactions costs respectively. Bernard \& Thomas (1989) and Louhichi (2008) advocate for intraday analysis of earnings announcements as new information exerts its full influence on the stock price within an hour after announcements. Following on the findings of a weak correlation of less than $10 \%$ by Lev (1989), Das, Pattanayak \& Pathak (2008) asserts that there is no clear direction of drifts in some markets following annual earnings announcements.

The post-earnings announcement drift (PEAD) or standardised unexpected earnings (SUE) is the tendency for a stock's cumulative returns to drift in the direction of a recent earnings surprise for several weeks following an earnings announcement (Ball \& Brown 1968, Chordia \& Shivakumar 2005, Livnat \& Mendenhall 2006 and Chordia et al 2009). This phenomenon depends on the market's expectation of earnings and the inflation illusion and has been observed to last for several weeks or even months. Livnat \& Mendenhall, 2006 suggest that investors who view the drift as a violation of market efficiency and hope to exploit it should also use the earnings surprise signal, or combination of signals, that maximises the drift. Various researches have been conducted across nations with varying degrees of support to the PEAD namely; the UK (Lonie et al. (1996), France (Gajewski \& Quéré (2001) and Putman, Griffin \& Kilgore (2008)), the USA (Cheon, Christensen \& Bamber (2001)), Australia (Chan, Faff \& Ramsay (2005)), China (Kong \& Taghavi (2006)) and lately Nigeria Campbell \& Ohuocha (2011))

\subsection{Tests and empirical research on the ZSE market efficiency}

A handful of researches have to date been carried out in order to ascertain whether the ZSE is information efficient (predominantly in the weak form). Several researchers found the market to be inefficient and these include Jefferis \& Okeahalam (1999b:p.131), Smith, Jefferis \& Ryoo (2002), Magnusson \& Wydick (2002), Mlambo, Biekpe \& Smit (2003), Jefferis \& Smith (2005), Sunde \& James (2006), Smith (2008), and Alagidede \& Panagrotidis (2009). A few researchers notably Jefferis \& Okeahalam (1999a) and Appiah-Kusi \& Menyah (2003) found the ZSE to be efficient suggesting that ZSE efficiency seems to vary depending on the time span adopted as well as the types of tests carried out.

Jefferis and Okeahalam (1999b:p.131) used the EVM to test the impact of earnings announcements on the abnormal return of a sample of stocks listed in the banking and financial services and retails stores industry sectors of the Botswana Stock Exchange (BSE), the ZSE and the Johannesburg Stock Exchange (JSE) using data over 52, 43 and 60 weeks respectively. Their findings showed semi-strong efficiency of the EMH for the JSE alone and rejections for ZSE and BSE. Mlonzi, Kruger \& Nthoesane (2011) finds substantial negative share price reaction to earnings announcements and evidence of weak form market efficiency characterised by shareholder wealth erosion during recessionary periods and 'opportunistic' profit taking when the market is performing well from studies on the JSE Altx during a recessionary year of 2009. 


\section{Sample and Methodologies}

\subsection{Sample and event definition}

Our analyses are based on all ZSE listed counters over the period 1 January 2010 to 31 December 2012 and we define two events of interest as follows:

1. The release to the public of a ZSE listed company's earnings announcements (full-year and half-year with or without a dividend).

2. The publication of a cautionary statement in public media by a ZSE listed company.

Data on the above was taken from the corporate announcements section of the ZSE website (http://wwww.zimbabwe-stock-exchange.com/corporate_announcements/), the African Corporate Announcements' website (http://www.africansens.com/) and verified using individual corporate websites were possible. A total of 329 events were identified of which 261 were earnings announcements (125 full-year, 117 half-year and 19 dividend) and 68 were cautionary statements.

In light of the various similar EVMs by Jefferis and Okeahalam (1999b: p.131), Brooks et al (2004), Lau, Shrestha and Yu (2010), Campbell and Ohuocha (2011) and Mlonzi, Kruger \& Nthoesane (2011), our event study timeline uses weekly returns and is specified as follows:

1. Estimation window: 18 weeks of weekly return observations beginning 21 weeks through to 3 weeks before the event [-21, -3] so it allows analysis of the impact of full/half-year financial results or cautionary without contamination of events.

2. Event window: ranges from 2 weeks before to 2 weeks after the event $[-2,+2]$. The event window for analysis therefore includes the week of the announcement and two weeks before and after the week in which the event is announced. This is also supported by the implicit 'short selling' in the ZSE Member Rules that gives period of $(T+7)$ days for settlement.

\subsection{The constant mean return model (CMRM)}

We adopt the constant mean return model (CMRM) framework as used by Brown and Warner (1980) and Campbell, Lo, and MacKinlay (1997), Chan-Lau (2001) and Brooks et al (2004). Our choice for the CMRM is motivated by its simplicity and robustness (Chan-Lau, 2001) as well as the evidence of its ability to provide similar estimates to those derived from more complex models (such as the market models, statistical (factor) models and economic models) because the variance of the abnormal return is not significantly reduced by the specification of more sophisticated models (Brown and Warner, 1980, 1985). We use logarithmic returns as outlined in Campbell and Ohuocha (2011) and refer detailed derivations and procedures underlying the CMRM assumptions to the above citations as well as Zivot (2000) and Strong (1992).

The key assumption underlying CMRM is that returns on stocks are jointly multivariate normal and are independent and identically distributed (iid) through time. Abnormal return $(A R)$ is the actual ex-post return of a security over the event window minus the normal return of the firm. The normal return is the expected return in the absence of the event taking place. The abnormal return for firm $i$ on event date $t$ is:

$A R_{i t}=R_{i t}-E\left(R_{i t} / I t\right)$

Where: $A R_{i t}, R_{i t}$, and $\mathrm{E}\left(R_{i t} / I t\right)$ are the abnormal, the actual and normal returns respectively, for time period $t$. $I t$ is the conditioning information for the normal return model computed in the estimation period, (Saidane and Lavergne (2007)).

Using the CMRM, abnormal returns $\left(A R_{i t}\right)$ in this study are therefore calculated as follows:

$A R_{i t}=\left(R_{i t}-\bar{R}_{i}\right) / \sigma i$

Where: $R_{i t}$ is the return on stock $i$ for week $t$,

$\bar{R}_{i}$ is the mean weekly return in a 18 week estimation period beginning 21 weeks through to 3 weeks before the event, and is the standard deviation of returns generated from the same estimation period.

This abnormal return can be viewed as a standardized abnormal return $S A R_{i t}$ where the mean and standard deviation are measured in another period (event estimation window).

The CMRM gives rise to the so-called random walk model of the logarithm of asset prices. The continuously compounded return $R_{i t}$, is defined from asset prices as follows: 
$R_{i t}=\ln \left(\frac{P_{i t}}{P_{i t-1}}\right)$

Where: $R_{i t}=$ stock return of company $i$ at time $t$,

$P_{i t}=$ stock price of company $i$ at time $t$, and

$P_{i t-1}=$ stock price of company $i$ at time $t-1$.

For each day in the event period, the cross-sectional standard deviation of the standardised abnormal returns is then calculated. This can be written as:

$$
\sigma S A R_{i}=\sqrt{\frac{\left(S A R_{i t}-\sum S A R_{i t} / N\right)^{2}}{N(N-1)}}
$$

The standardised cross-sectional statistic is thus:

$$
Z=\frac{\sum S A R_{i t} / N}{\sigma S A R_{i}}
$$

The individual standardised abnormal returns are assumed to be cross-sectionally normal and iid. By the LindbergLevy and Lindberg-Feller central limit theorems (Greene, 2000), the distribution of the sample average standardised abnormal returns will converge to normality. Boehmer et al (1991) report that the test is correctly specified even when there is a variance increase in the event period. We specify our null $\left(\mathrm{H}_{0}\right)$ and alternative $\left(\mathrm{H}_{1}, \mathrm{H}_{2}, \mathrm{H}_{3}, \mathrm{H}_{4}, \mathrm{H}_{5}\right.$, ) hypotheses based on the cumulative abnormal return (CAR) as follows:

$\mathrm{H}_{0}$ : earnings announcements/dividend declarations/cautionary statements have no significant impact on returns on the ZSE i.e.

$\mathrm{H}_{1}$ : Combined earnings announcements/dividend declarations/cautionary statements have a significant impact on returns on the ZSE i.e.

$\mathrm{H}_{2}$ : Full year earnings announcements have a significant impact on returns on the ZSE i.e.

$\mathrm{H}_{3}$ : Half-year earnings announcements have a significant impact on returns on the ZSE i.e.

$\mathrm{H}_{4}$ : Cautionary statements have a significant impact on returns on the ZSE i.e.

$\mathrm{H}_{5}$ : Dividend declarations have a significant impact on returns on the ZSE i.e.

We carry out two sets of tests as follows:

1. Two tailed test at the $5 \%$ level of significance and reject of $\mathrm{H}_{0}$ (the null hypothesis) if the value of our calculated CAR test statistic is greater than 1.96 (or p-value $<0.025$ ).

2. Two tailed test at the $10 \%$ level of significance and reject of $\mathrm{H}_{0}$ (the null hypothesis) if the value of our calculated CAR test statistic is greater than 1.645 (or $p$-value $<0.05$ ).

\subsection{Ethics statement}

This research made use of primary data that already has ethical documentation and only did secondary analysis. Any sensitive company experiences are masked beyond specific identification by future researchers and users of this paper.

\section{Findings and discussions}

\subsection{Stock ARs around an event}

Figure 1 shows the stock average abnormal returns (AARs) for each week from week -2 through to week +2 for all the announcements made on the ZSE from 2010 to 2012 (i.e. for the full period). On the event week (week 0), the event stocks have an AAR of 0.0199 percent which has a trough on the announcement week before going through a short-term post-event reversal to its pre-event levels. Cautionary statements and full-year earnings experience negative AARs in the event week while half-year earnings and dividends have positive AARs. Pre and post-event AAR are largely positive with the exception of dividends on week -2 , half year announcements week -1 and for cautionary statements on week +1

We note that the AAR for dividends are positive as from week -1 and peak on the event announcement. This suggests some level of anticipation from the market and the new information is quickly assimilated by the market and a new price level is set. The announcement of annual earnings leads to a dip in AARs before reverting back to the pre event announcement level, suggesting the presence of some 'selling off' pressure on the stock. There seems to be mild reaction to half year results announcements while cautionary appear to stabilise the price to its estimation window average suggesting that board and management may be using cautionary statements to minimise negative abnormal returns. 


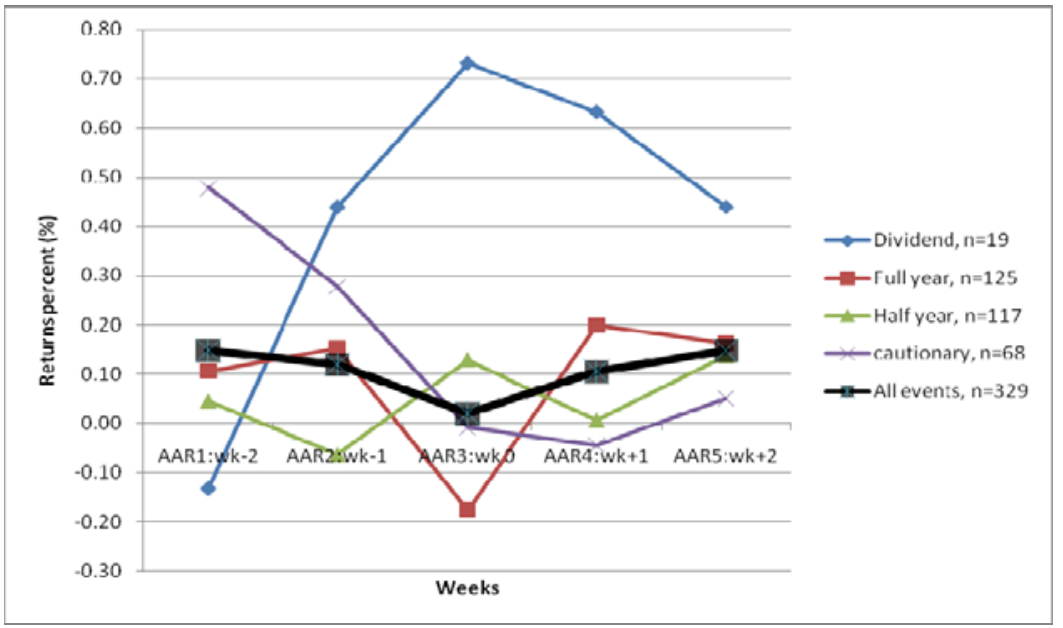

Figure 1: AARs (\%) during the event window

\subsection{Distribution Stock ARs across the events}

CARs shown in Table 1 for all events as well as the split events were positive with means ranging from a low value of $0.26 \%$ for half-year results and a significantly high value of $2.11 \%$ for dividends. Observation shows the CARs distributions to be positively skewed for all the events although the half-year earnings appear normal in shape (mesokurtic) with kurtosis of almost 3 and a mean almost equal to the median. All events and dividends exhibit a leptokurtic shape, whereas full-year earnings and cautionary statements appear platykurtic in nature, (Brooks 2008:p.162).

Table 1: Statistical measure of the CARs across events

\begin{tabular}{|l|c|c|c|c|c|}
\hline & All events & Full-year & Half-year & Cautionary & Dividends \\
\hline Mean & 0.5389 & 0.4455 & 0.2585 & 0.7537 & 2.1114 \\
\hline Median & 0.2278 & 0.1712 & 0.2241 & 0.2003 & 1.1076 \\
\hline Skewness & 0.7324 & 0.5950 & 0.7420 & 0.4196 & 1.3602 \\
\hline Kurtosis & 2.6767 & 0.1727 & 3.0985 & 1.8057 & 2.9277 \\
\hline Mean of Absolutes & 2.1408 & 1.8016 & 2.1188 & 2.5906 & 2.8974 \\
\hline Proportion of positive CARs & 0.5335 & 0.5161 & 0.5385 & 0.5294 & 0.6316 \\
\hline
\end{tabular}

Table 1 reveals what appears to be a balanced proportion between positive and negative for all events and the other spilt events with positives having a proportion averaging $53 \%$ while dividends have a high proportion of positives at $63 \%$. Averaging the absolute (the sum of the averages of positive and negative values when aggregated separately based on a benchmark of zero, (CT8, 2005: p.74) values gives a feel how the CARs are distributed between positive and negative values in absolute sense looking at the average distance of each group of observations from zero. Thus given an event window benchmark of zero, the positive AR displacement outweighs that in the negative direction, suggesting a higher tendency towards positive ARs.

\subsection{Hypothesis tests and p-values for stock price ARs}

There was substantial evidence in support of the null hypothesis $\left(\mathrm{H}_{0}\right)$ in all the tests listed in Section 3.3 and the test decisions at $5 \%$ and $10 \%$ levels of significance. We observe that share prices of ZSE-listed companies over the years 2010 to 2012 earned no significant abnormal returns as shown in Table 2. 
Table 2: Summary of Hypothesis Test on Cumulative Abnormal Returns (CARs)

\begin{tabular}{|l|c|c|c|c|c|}
\hline & All events & Full-year & Half-year & Cautionary & Dividends \\
\hline CAR & 0.5389 & 0.4455 & 0.2585 & 0.7537 & 2.1114 \\
\hline Std Dev of CAR (O' $)$ & 3.0130 & 2.3388 & 3.1340 & 3.5652 & 3.7113 \\
\hline z-value (CAR/Ơ') & 0.1789 & 0.1905 & 0.0825 & 0.2114 & 0.5689 \\
\hline Test of $H_{0}$ at $\%, 10 \%$ & Accept & Accept & Accept & Accept & Accept \\
\hline p-value & 0.4290 & 0.4245 & 0.4671 & 0.4163 & 0.2847 \\
\hline
\end{tabular}

Figure 2 below shows the calculated $p$-values for all the events superimposed on the cumulative number of observations for the given $\mathrm{p}$-value. There are very few (11 in total) instances where $\mathrm{H}_{0}$ was rejected at the $10 \%$ level of significance for a two tailed test.

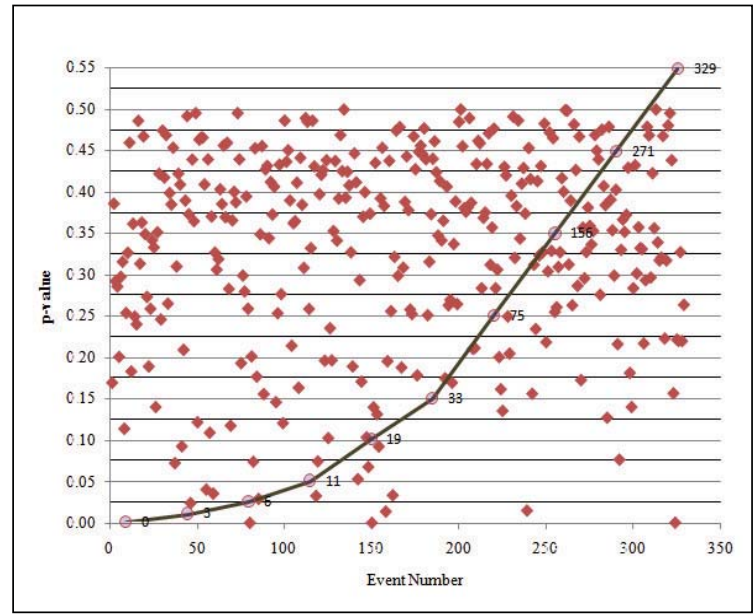

Figure 2: $p$-values and cumulative number of observations for CAR tests

We explore the impact of significant 'good news' and 'bad news' separately by considering a one tailed test scenario at the $10 \%$ level, according to Figure 2, there would be 19 rejections of the $\mathrm{H}_{0}$, which is $6 \%$ of the total observations. The $\mathrm{p}$ values bellow $10 \%$ are made up of $74 \%$ 'good news' (positive) events and $26 \%$ 'bad news' (negative) events. Examining the correlation between 'bad news' and the direction of CARs shows a matching of $68 \%$ where the signs are identical suggesting that very few firms $(4 \%=6 \% * 68 \%)$ on the ZSE experience significant symmetric abnormal returns. Thus the significant CARs reveal a very weak correlation of 0.04 between earnings announcements and abnormal returns without a clear direction of drifts.

\section{Concluding remarks}

Our study considered the stock market impact major of announcements on the ZSE in order to assess the extent of information assimilation as brought about by earnings announcements (full-year, half year and dividend declarations) and cautionary statements and then analysed the events that were deemed significant. The event window CARs for all the 329 announcements and for the subsamples of 125 Full-year, 117 Half-year, 68 Cautionary and 19 Dividend, were all found to be not different from zero. We can therefore conclude that earnings announcements and cautionary statements have no significant impact on returns on the ZSE.

ZSE investors seem not to react to short-term news on the ZSE, since most of the investors on the ZSE are institutional who have a long-term view and hence more interested in the potential upside from the undervalued market, hence the higher tendencies towards slight positive ARs displacement than the negative ARs. High total costs of trading of $4.21 \%$ for the buying and selling of stocks on the ZSE may also be an inhibitor to the realization of abnormal returns in the short term as they are almost double the highest observed mean AR from dividend announcements. The low liquidity 
prevailing on the ZSE during the period of our study suggests that investors may be 'locked' in a particular counter due to the uncertainty in matching buyers of the undesired stock with sellers of the desired one timely and in value terms. The noise from the implementation of the indigenization law as well as the uncertain political environment might have suppressed foreign investor activity thereby suppressing the performance of the ZSE. Allegations of poor corporate governance, price manipulation and insider trading may place abnormal returns in the estimation window making it difficult for event study methodology to detect abnormalities. The definition of a 'bad news' event and a 'good news' event would require input from market participants (analysts, brokers and investors) and company executives due to the current recovery nature of our market and hence our exclusion of year 2009.

Overall for the Zimbabwean stock exchange (ZSE), we conclude that earnings announcements in their stated forms and cautionary statements, either good or bad, have no significant impact on the weekly returns of listed stocks. This point to the absence of signalling on the local market and paints a picture that theZSE is efficient in accordance with the efficient market hypothesis (EMH). Although the research was conducted during a recessionary period similar to Mlonzi, Kruger \& Nthoesane (2011), our results are different. Our results fall in the minority and add to the work by researchers such as Lev (1989) and Das, Pattanayak \& Pathak (2008). The paper lays a foundation for future researches along the direction of this paper and we recommend explorations on varying choices of event study windows as well as the use of daily/monthly ZSE returns in line with Hood (2012), Bernard \& Thomas (1989) and Louhichi (2008).

\section{References}

Aharony, J. and Swary, I. (1980). Quarterly dividend and earnings announcements and stockholders' returns: An empirical analysis,Journal of Finance, 35(1): 1-12

Alagidede P., and Panagiotidis, T., (2009). Modelling stock returns in Africa's emerging equity markets. International Review of Financial Analysis, 18, 1-11

Appiah-Kusi J. and Menyah K. (2003). Return predictability in African stock markets, Review of Financial Economics, 12(3), 247-270

Ball, R., and Brown, P., (1968). An empirical evaluation of accounting income numbers, Journal of Accounting Research 6, 159-178

Barker, R. and Imam, S. (2008). Analysts' perception of earnings quality, Accounting and Business Research, 38(4): 313-328

Bernard, V. and Thomas, J. (1989). Post earnings announcement drift: Delayed price response or risk premium, Journal of Accounting Research, 27: 1-36

Bhana, N. (1995/96). 'The share market reaction to earnings announcements: A test of the efficiency of the Johannesburg Stock Exchange', Investment Analysts, 42: 45-57

Binder, J.J. (1998). The Event Study Methodology Since 1969, Review of Quantitative Finance and Accounting, 11: 111-137

Brooks R., Faff R.W., Hillier D., and Hillier J. (2004). The National Market Impact of Sovereign Rating Changes, Journal of Banking \& Finance vol.28, issue 1, pages 233-250

Brooks, C. (2008). Introductory Econometrics for Finance, Cambridge Univ. Press, 2nd Ed.

Brown, S. and Warner, J., (1985). Using Daily Stock Returns: The Case of Event Studies, Journal of Financial Economics 14, pp. 3-31

Brown, S., and Warner J., (1980). Measuring security price performance, Journal of Financial Economics 8, p.205-258

Campbell, J.Y, Lo A.W. and MacKinlay A.C., (1997). The Econometrics of Financial Markets, Second Edition, Princeton: Princeton University Press

Campbell, K. and Ohuocha, C., (2011). The stock market reaction to stock dividends in Nigeria and their information content, Managerial Finance, Vol. 37 Iss: 3 pp. $295-311$

Chan, H., Faff, R. and Ramsay, A. (2005). Firm size and the information content of annual earnings announcement: Australian evidence, Journal of Business Finance and Accounting, 32(1): 211-253

Chan-Lau J.A., (2001). Corporate Restructuring in Japan: An Event Study Analysis, International Monetary Fund, WP/01/2012: pp. 9

Charest, G. (1978). Dividend information, stock returns and market efficiency-II, Journal of Financial Economics, 6, 297-330

Cheon, Y.S, Christensen, T.E. and Bamber, L.S. (2001). Factors associated with differences in the magnitude of abnormal returns around NYS Eversus NASDAQ firms' earnings announcements, Journal of Business Finance and Accounting, 28(9): 1073-1108

Chesney, M., Reshetar, G. and Karaman, M. (2010). "The Impact of Terrorism on Financial Markets: An Empirical Study" (available on www.ssin.com)

Chinamasa P. (2009). 2009 Budget Statement for the Republic of Zimbabwe, p.4-5

Chordia, T. and Shivakumar, L. (2005). Inflation illusion and post-earnings announcement drift, Journal of Accounting Research, 43(4): 521-556

Chordia, T., Goyal, A., Sadka, G., Sadka, R. and Shivakumar, L. (2009). Liquidity and the post-earnings announcement drift, Financial Analysts Journal, 65(4): 18-32

Christensen, T.E., Smith, T.Q. and Stuerke, P.S. (2004). Public pre-disclosure information, firm size, analyst following, and marketreactions to earnings announcements, Journal of Business Finance andAccounting, 31(7): 951-984

CT8, (2005). Actuarial Education Company, Financial Economics Study Guide

Das, S., Pattanayak, J.K. \& Pathak, P. (2008). The effect of quarterly earnings announcements on Sensex: A case with clustering of events, ICFAI University Journal of Accounting Research, 7(4): 64-78 
Deshpande, S., Svetina, M., (2011). Does local news matter to investors?, Managerial Finance, Vol. 37 Iss: 12 pp. 1190 - 1212

Dey, M.K. and Radhakrishna, B. (2008). Who profits from trading around earnings announcements? Evidence from TORQ data, Journal of Asset Management, 9(4): 300-308

Fama, E.F., Fisher, L., Jensen, M., and Roll, R. (1969). The Adjustment of Stock Prices to New Information, International Economic Review 10, 1-21

Gajewski, J. and Quéré, B.P. (2001). The information content of earnings and turnover announcements in France, European Accounting Review,10(4): 679-704

Graca, T. and Masson, R. (2012)."More power to you: properties of a more powerful event study methodology", Review of Accounting and Finance, Vol. 11 Iss: 2 pp. 166 - 183

Hood, M., (2012). The Tiger Woods scandal: a cautionary tale for event studies, Managerial Finance, Vol. 38 Iss: 5 pp. 543 - 558

Jefferis K., and Okeahalam C.C., (1999a). International Stock Market Linkages In Southern Africa, South African Journal of Accounting Research,Vol. 13, No. 2, pp 1-25

Jefferis, K., and Okeahalam, C.C., (1999b). An Event Study of the Botswana, Zimbabwe and Johannesburg Stock Exchanges, South African Journal of Business Management, Vol. 30, No. 4, p.131-140

Jefferis K., and Smith G., (2005). The changing efficiency of African stock markets, South African Journal of Economics, Vol. 12, No. 1, 54-67

Kong, S. \& Taghavi, M. (2006). The effect of annual earnings announcements on the Chinese Stock Markets, International Advances in Economic Research, 12: 318-326

Lau, S.T., Shrestha, K., and Yu, J., (2010). Are earnings announcements informative? A cross-country analysis; Accounting \& Finance Association of Australia \& New Zealand (AFAANZ) Conference 4-6 July 2010; Available from: http://www.afaanz.org/conferences

Legat J. (2009). The 'New' Zimbabwe: A Rapid Recovery from a Low Base, Imara Investment Notes

Lev, B. (1989). On the usefulness of earnings and earnings research: Lessons and directions from two decades of empirical research, Journal of Accounting Research, 27: 153-201

Livnat, J. and Mendenhall, R.R. (2006). Comparing the post-earnings announcement drift for surprises calculated from the analyst and time series forecasts, Journal of Accounting Research, 44(1): 177-205

Lonie, A.A., Abeyratna, G., Power, D.M. \& Sinclair, C.D. (1996). The stock market reaction to dividend announcement. AUK study of complex market signals, Journal of Economic Studies, 23(1): 32-52.

Louhichi, W. (2008). Adjustment of stock prices to earnings announcement: Evidence from Euronext Paris, Review of Accounting Finance, 7(1): 102-115

Mackinlay, A.G., (1997). Event studies in economics and finance, Journal of Economic Literature, 35: 13-39

Magnusson M.A and B. Wydick (2002). How efficient are Africa's Emerging Stock Markets?, The Journal of Development Studies, Vol. 38, No.4, pp 141-156

McClusky, T., B.M. Burton, D.M. Power and C.D. Sinclair. (2006). Evidence on the Irish stock market's reaction to dividend announcements, Applied Financial Economics,16,617-28.

McNichols, M. and Dravid, A. (1990). Stock dividends, stock splits, and signalling, The Journal of Finance, Vol. 45 No. 3 , pp. 857-79

Mendenhall, R. (1991). Evidence of possible underweighting of earnings-related information, Journal of Accounting Research, 29: 394417

Mlambo C, Biekpe N and Smit E. vd.M., (2003). Testing the Random Walk Hypothesis on Thinly-Traded Markets: The Case of Four African Stock Markets, The African Journal of Finance, 5(1), 16-35

Mlonzi, V.F., Kruger J., and Nthoesane, M.G. (2011). Share price reaction to earnings announcement on the JSE-ALtX: A test for market efficiency, Southern African Business Review, 15(3):142-166

Mushidzi, T.B. and Ward, M. (2004). Abnormal returns for cash vs share funded acquisitions, Investment Analysts Journal, 60: 17-32

Putman, R.L., Griffin, R.B. and Kilgore, R.W. (2008). The impact of earnings management on capital markets: Ethical consideration of the players, Journal of Legal, Ethical and Regulatory Issues, 11(2): 139-145

Saidane, M. and Lavergne, C. (2008). A New HMM Learning Algorithm for Event Studies: Empirical Evidence from the French Stock Market, AERB Applied Economics Research Bulletin-Berkeley-USA -Vol. 1, Fall 2008, pp. 1-30. Available on: http://citeseerx.ist.psu.edu/viewdoc/download?doi=10.1.1.111.6840\&rep=rep1\&type=pdf

Smith G, Jefferis K, and Ryoo H, (2002). African stock markets: multiple variance ration tests of random walks, Applied Financial Economics Vol.12, No. 7, pp 475-484

Smith G. (2008). Liquidity and the Informational Efficiency of African Markets, South African Journal of Economics, 76(2), 161-175

Sponholtz, C. (2008). The information content of earnings announcements in Denmark, International Journal of Managerial Finance, 4(1): 4-36

Strong, N., (1992). Modeling abnormal returns: A review article, Journal of Business Finance and Accounting, 19: 533-553

Sunde T and James Z. (2006). The Random Walk Hypothesis for the Zimbabwe Stock Exchange: January 1998- November 2006. Journal of Social Sciences, 4(3), 216-22. Available on: www.fma.org/SLC/Papers/DoStockSplitsReallySignal.pdf

The Central African Stock Exchanges Handbook (2011). The New Zanj Publishing House.

The Zimbabwe Stock Exchange Handbook (2010). Zfn, The New Zanj Publishing House.

Zivot, E., (2000). Introduction to Financial Econometrics, University of Washington

Bulls n Bears Financial Markets Update, (27 July 2012). Bullish Thoughts: Insider trading still rampant on the ZSE

The Zimbabwe Independent, (28 October 2011). ZSE Special Bargains Concern SEC 
The Zimbabwe Standard, (4 March 2010). ZSE trading vulnerable to manipulation - analysts

The Zimbabwe Herald, (Friday 27 April 2012). CBZ, ZB off the hook

The Zimbabwe Stock Exchange website, www.zse.co.zw

The African Corporate Announcements website, http://www.africansens.com/

The African Economic Outlook 2012 - Zimbabwe, (AfDB, OECD, UNDP, UNECA), www.africaneconomicoutlook.com 